\title{
CEO's Emotional Commitment Level and its Firm Capital Structure Choice: Decision Tree Analysis
}

\author{
AZOUZI Mohamed Ali ${ }^{1} \ltimes$ \\ JARBOUI Anis ${ }^{2}$ iD
}

Assistant Professor in Finance and Accounting Methods Higher Institute of Business Administration (ISAAS) University of SFAX Postal Address: ISAAS, Sfax-Tunisia

Email:Mohamed_azouzi@yahoo.fr.

${ }^{2}$ Doctor and HDR Financial and Accounting Associate Professor of Universities Higher Institute of Business Administration (ISAAS) University of Sfax Postal Address: ISAAS, BP 1013 - 3018 Sfax-Tunisia

Email:anisjarboni@yahoo.fi.

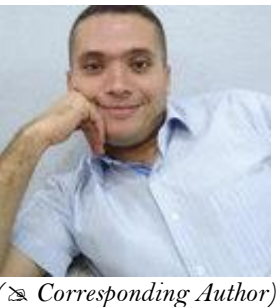

\begin{abstract}
This research examines the determinants of firms' capital structure introducing a behavioral perspective that has received little attention in corporate finance literature. After discussing the theoretical linking between firm capital structure choice and the CEO's attitude and behavior, we are showing on empirical grounds the relationship between the manager's behavior toward the capital structure preferences and his cognitive commitment level. The article explains that the main cause of capital structure choice is CEO commitment level. We introduce an approach based on Decision Tree Analysis technique with a series of semi-directive interviews. The originality of this research is guaranteed since it traits the behavioral corporate policy choice in emergent markets. In the best of knowledge this is the first study in the Tunisian context that explores such area of research. Results show that psychological dimension introduced in the capital structure analysis has enriched the Pecking Order Theory (POT) and the Static Trade Off Theory (STT) CEO (CEO affective commitment) prefer to finance their projects primarily through internal capital, by debt in the second hand and finally by equity.
\end{abstract}

Keywords: Emotional bias, CEO commitment level, Corporate finance, Capital structure choice, Decision tree.

JEL Classification: G3; G4; L1; L2

Citation | AZOUZI Mohamed Ali; JARBOUI Anis (2018). CEO's Emotional Commitment Level and its Firm Capital Structure Choice: Decision Tree Analysis. Asian Journal of Economics and Empirical Research, 5(1): 65-78.

History:

Received: 26 February 2018

Revised: 17 July 2018

Accepted: 24 July 2018

Published: 31 July 2018

Licensed: This work is licensed under a Creative Commons

Attribution 3.0 License (cc) E E

Publisher:Asian Online Journal Publishing Group
Contribution/Acknowledgement: Both authors contributed to the conception and design of the study.

Funding: This study received no specific financial support.

Competing Interests: The authors declare that they have no conflict of interests.

Transparency: The authors confirm that the manuscript is an honest, accurate, and transparent account of the study was reported; that no vital features of the study have been omitted; and that any discrepancies from the study as planned have been explained.

Ethical: This study follows all ethical practices during writing.

\section{Contents}

1. Introduction

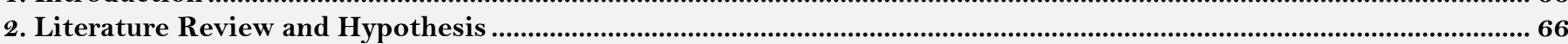

3. Research Method ......... 69

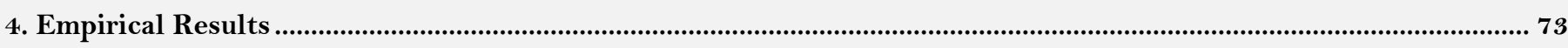

5. Conclusion 76

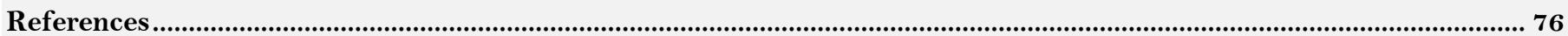




\section{Introduction}

The main changes recorded in financial theory, including consideration conflicts of interest between agents, information asymmetries, the optional nature of financing, asset specificity have significantly closer approach theoretical reasoning actually observed in practice.

Theories of Trade-off (Static Trade-off Theory, STT) and Pecking Order (Pecking Order Theory) are the theoretical corpus of reference addressed the issue of the structure financial position of the firm. The first (STT) based on a trade-off between costs (explicit or implicit bankruptcy) and gains (values tax savings) debt-related to obtain an optimal financial structure maximizing the value of the firm. with against the second ignores the concept of optimal capital structure and argues that the choice of funding is through a hierarchical order.

However, despite the contributions of these approaches to corporate finance several decisions are not understood. Indeed, if we accept eg trade-off, the structures observed funding can be either without adjustment costs and structure with optimal ratios or goods with adjustment costs and poach the optimum ratios (Ross, 1977; Jalilvand and Harris, 1984; Mayers and Majluf, 1984; Titman and Wessels, 1988; Stulz, 1990; Graham, 2000; Booth et al., 2001). Booth et al. (2001) argues the presence of a discrepancy between the theoretical predictions (STT and POT) analysis of the capital structure of companies and the distribution of this structure in reality.

Many contemporary researchers have emphasized the importance of leaders values and objectives in explaining corporate financing structure (Barton and Gordon, 1987; Barton et al., 1989). Indeed, the individual arguments are shortcuts influencing cognitive stance, making irrational and suboptimal under traditional financial theories. These biases have been identified and classified and include the follows: The representativeness bias, analog reasoning conservatism bias and confirmation, but also emotions such as loss aversion, optimism and overconfidence. In this sense, several authors have updated the old idea that emotions an adaptive role. Emotions are necessary for the functioning of many of our faculties, such as memory, reasoning, decision-making.

Goleman et al. (2001) asserts that the emotional part of our brain is the basis of development of our thinking and, ultimately, our lives. It is this which explains our successes and our failures. Graham (2000) says that insofar as our emotions or block amplify our ability to think and plan, learn to achieve a goal distant, solve problems, etc., they define the limits of our ability to use our innate mental abilities and therefore decide our future.

The leader attitude, such as commitment, positively influences the ability to assess alternatives. According to Baker et al. (2011) to contemporary organizations, it is not enough more to recruit and retain workers but they must also inspire and give them the ability to deploy the most of their skills in their duties. Companies have therefore need people who are psychologically related to their work and their organization wishing invest more in their roles, in other words, today's businesses need workers engaged.

It is therefore interesting to transpose the bias identified in behavioral finance study behavior of leaders faced with choices of financing and investment. This is the path taken by the current managerial optimism. Assumptions neglect the existence of information asymmetries and conflicts of interests between the leaders - shareholders and introduce behavioral biases leading executives to be engaged, optimistic or overly confident in their skills and future revenues firm.

The presence of these biases we bring to the questioning of the effectiveness of decisions managerial (political financing) and the integration of behavioral dimension in explaining the policy of corporate finance.

On this basis, the aim of our research is to integrate the behavioral dimension in the analysis of financing choices leaders: our goal is to show the effect of the managerial commitment to its choice of financing.

\section{Literature Review and Hypothesis}

Individual reasoning with cognitive shortcuts that influence the position, irrational and non-optimal in terms of conventional financial theories making. These biases have been identified and classified and include the following terms: The representativeness bias, analog reasoning bias conservatism and confirmation, but also emotions such as loss aversion, optimism, overconfidence and emotional commitment. In this sense, many contemporary researchers have updated the old idea that emotions have an adaptive role. Emotions are necessary for the functioning of many of our faculties, such as memory, reasoning, decision-making or social adjustment.

Research has frequently demonstrated the influence of affect on attitudes and behavior (Garg et al., 2007). Recent years have thus emphasized the predominant role of emotion as an enabler for decision making on the one hand and as one of the key regulators of behavior, on the other hand (Philippot, 2007).

The behavioral finance literature that examines the consequences of behavioral biases of managers has primarily focused on managerial loss aversion, optimism and overconfidence; traits that have been shown to be prevalent in managers (Malmendier and Tate, 2005;2008).

In this paper, we extend the results of our study conducted in the Tunisian context in 2012 (Azouzi and Jarboui, 2012).We examine an alternative explanation based on differences in managerial beliefs to shed light on some of the unexplained variation in capital structure decision. We examine the role of CEO behavioral characteristics (emotional commitment) in the design of capital structure choice. Hence, in this section, the central objective consists in highlighting the type of relationship existing between emotional commitment and the capital structure choice : the first part consists in emotional commitment construct and the second part show relationship between emotional commitment and the capital structure choice.

\subsection{Emotional Commitment Concept (EC)}

\subsubsection{Definition}

Tsai (1999) defined organizational commitment as the identification with the organization and willingness to make extra efforts for the organization to achieve organizational goals (Lee et al., 2014).

Robbins (2001) believed that organizational commitment is the level of loyalty to and identification with an organization, as well as the involvement in organizational activities (Lee et al., 2014). 
Meyer and Allen (1991) define commitment:" as a Psychological state that characterizes the employee's relationship with the organization and has implications for the decision to continue or discontinuous membership in the organization "(Meyer and Allen, 1991).

For these authors, if the commitment is a psychological state that reflects the relationship of employees in their organization, the concept now has several dimensions. Their approach built the commitment to a multidimensional three components: a component "emotional", a component of "continuation" and a component "normative".

In our study, is interested in the emotional commitment component. Thus, Meyer and Allen (1991) define Emotional commitment:" refers to identification and emotional attachment to the company". This type of commitment is interested in the will of the individual to adhere to what the organization stands for. The individual engaged emotionally, identifies, engages and is happy to be a member of the company for which he works (Allen and Meyer, 1990; Meyer and Allen, 1997).

\subsubsection{Commitment Organizational Model: Three-Component Model of Organizational commitment (TCM) (Allen and Meyer, 1996)}

There are currently at least three active approaches to measuring organizational commitment: the Organizational Commitment Questionnaire by Mowday et al. (1979) the Identification/Internalization Typology by O'Reilly and Chatman (1986) and the Three-Component Model of organizational commitment (TCM) by Meyer and Allen (1991;1997). Among these approaches, the TCM is widely regarded as the most dominant model in organizational commitment research (McDonald and Makin, 2000; Greenberg and Baron, 2003; Cohen, 2003;2007; Bentein et al., 2005; Solinger et al., 2008).

Allen and Meyer (1990) argued that organizational commitment is a multiple construction and can be divided into personal emotions, costs and risks perceived and social relationships. Organizational commitments can be decomposed into (1) affective commitment: the level of emotional attachments toward an organization; (2) continued commitment: perceived costs and risks regarding the departure from the organization; and (3) normative commitment: a moral commitment, the responsibility and obligation felt toward the organization. These dimensions describe the different ways of organizational commitment development and the implications for employees' behavior.

\section{Affective Commitment}

Largely inspired by the work of Porter et al. (1974) we chose to use the measuring instrument developed by Allen and Meyer (1990) to measure organizational commitment emotional guy. Affective commitment involves three aspects: creation, emotion setting to the organization, identification and desire to maintain organizational membership. According to Meyer and Allen (1997) affective commitment is "the employee's emotional attachment to, identification with and involvement in the organization". Their model target how the individual feels committed to the location of the employing organization, taking into account the positive feelings of identification, attachment and involvement.they indicate that affective commitment is influenced by factors such as employment challenge, the role clarity, clarity of purpose and the purpose of the difficulty, responsiveness by management, peer cohesion, equity, self-importance, comments, participation and reliability.

\subsubsection{Emotional Commitment, Academic Performance and Social Interactions}

The consequences of affective commitment on organizational behavior have a significant justification for interest in this concept. Essentially because it is associated with favorable outcomes such as lower turnover rates and increased job performance and organizational citizenship behavior (Meyer et al., 2002). Among the various forms of commitment that have been studied, the affective dimension, which reflects employees' identification and involvement with the organization (Meyer and Allen, 1991) has been found to be the most strongly associated with work outcomes (Meyer et al., 2002).

Studies that have focused on the consequences of organizational commitment demonstrates the importance for public and private organizations, employees highly engaged emotionally. Meyer and Allen (1997) reported that an employee strongly committed emotionally present greater motivation or a greater desire to contribute significantly to the organization. It will work with more zeal and will have a higher return. He will direct his attention to the performance aspects of his work that he considers valuable to the organization. He will receive a congruence between its objectives and those of his organization.

Rocha et al. (2008) say that organizational commitment not only has positive influences on organizations, but also beneficial to individual employee and the society as a whole. It benefits employees themselves in such a way that emotional and financial instability can be reduced by lower turnover rate. The achievement of in-role performance could be affected by employees' affective commitment to the organization (Swailes, 2004). Affective commitment is an employee's desire to stay as a member of the organization, an intention to make an effort for the organization, a belief in the values and norms of the organization (Glazer and Kruse, 2008) and emotional attachment to the organization. This affective commitment is a driving force that makes employees contribute to the improvement of the organization's performance (Lee et al., 2014).

\subsection{Hypothesis}

\subsubsection{CEO'S Emotional Commitment and Internally Generated Resources Choice}

The most common approach in the literature is undoubtedly emotional commitment, which is defined as the identification and emotional attachment of an employee to his company (Meyer and Allen, 1997). According to the literature, affective commitment would encourage positive attitudes and behaviors at work. As highlighted individuals emotionally committed to their business would be more willing to develop favorable towards it attitudes and to show willing to contribute voluntarily to the proper functioning.

Affective commitment is positively related to positive discretionary behaviors (Shore and Wayne, 1993; Organ and Ryan, 1995; Allen and Meyer, 1996). So any CEO engaged threatened by the risk of loss of social status seeking to value his work at the head of his company through effective financial choices. Helliar et al. (2005) argue 
that the loss showers leaders seek to avoid the most pessimistic. scenarios They do not would use the management tools risk to reduce the variance of cash flows but rather to avoid the worst scenarios pessimistic influencing the risk of bankruptcy or preventing the company to benefit profitable investment to value his work at the head of his company through effective financial choices. It therefore avoids choice of methods of risk financing (debt: bankruptcy risk and equity: takeover risk ) and preferred financing internal capital.

Somers and Birnbaum (2000) state leaders committed both to their profession and their company appear more positive attitudes and behaviors for the organization, including better and a lower satisfaction and greater involvement in work propensity to leave the organization. These highly committed leaders opt for projects riskier investment (including investment innovation). This investment requires the risky choice to prefer self-financing in order to escape the risk premium required by providers of external capital. This implies the presence of a positive relationship between internally generated resources preferences and CEO emotional commitment level.

Kundi et al. (2007) Show that the CEO emotional commitment level its encourages to undertake the efficiency choice.A committed leader seeks to avoid the adverse consequences of financial distress (loss of brand image on the market leaders ...). He prefers to finance its investments by internal capital at the expense of external financing modes (risky).

Girandola and Michelik (2008) assume that the leaders strongly committed tend to be more optimistic. Hilary and Menzly (2006) added that financial analysts in situations of overconfidence and optimism (emotional commitment high level) tend to move away from the consensus predictions apart by delivering the reality of more than $10 \%$. The same idea, always take an engaged leader that his company is undervalued by the market. The leader must take into account the risk and uncertainties regarding fluctuations in stock prices and takeovers. So it will save the maximum to be financed by the market (capital increase).

H1: An engaged leader accepts a internally generated resources level greater than that debt (and / or equity).

\subsubsection{CEO'S Emotional Commitment and Debt Choice}

Meyer et al. (2004) suggested that commitment level is part of the motivation. They showed that the CEO commitment level is positively correlated with its motivation. This committed leader (motivated) looking through strategic choices (including debt financing decision) report the performance of its business. Thus, modeling financial decisions proposed by Mayers and Majluf (1984) how show the level of debt can be used to solve the problem of asymmetric information between leader and markets (investors). The leader chosen for debt project finance and performance reports (maximizes shareholder wealth in place and refuse the entry of new shareholders) of the firm that pushes analysts to reassess.

De Clercq et al. (2009) found that CEO'S Emotional commitment positively impacts start-up and venture performance. Thus, the committed leader opts for debt to take advantage of its tax savings (the most successful companies are the most indebted is the Static Trade-off Theory), create value for shareholders and to report its performance on the market leaders.

Chang et al. (2009) states that managers overestimate their power to reduce risks within the business. Bertrand and Sendhil (2003) point out that the reputation leaders can lead them to prefer to imitate the decisions of their predecessors efficient, ignoring the return on investment. This mimicry appears depending on the CEO commitment level, age and the uncertainty of its environment. Indeed it is committed leader downpour in the reputation loss or employment chooses a distribution policy more generous than its predecessors dividends (Azouzi and Jarboui, 2012). It meets the expectations of its shareholders in terms of changes in the rate of dividend distribution. It uses the borrowing capacity of the company. They also underestimate bankruptcy probability and therefore issue a higher debt level.

Luthans and Youssef (2007) show that organizational commitment is positively related with optimism. Fairchild (2009) adds that optimistic leader (high emotional commitment level) overestimates the capacity of its business and underestimate the costs of financial distress. This evaluation bias (hopefully) makes him choose debt as a financing of these investment projects. Thus, Malmendier and Tate (2005;2008); Malmendier and Tate (2015) find that the optimistic manager will give priority to self-financing, then debt and ultimately to the issuance of shares. Thus, if the flow of the company is insufficient capacity, it is useful to resort to external financing. The optimistic leader always prefers debt (reported by debt) to the capital increase: the Pecking Order Theory (Azouzi and Jarboui, 2012).

Humphreys et al. (2005) observed a positive correlation between CEO Emotional Intelligence and commitment level (Carmeli, 2003; Rosete and Ciarrochi, 2005). Siu (2009) indicates the presence of a positive correlation between emotional intelligence and effective decision-making. The author maintains a high level of emotional intelligence is positively associated with low suggestibility of behavioral biases. Thus, emotion regulation refers to actual useful skills to cope with the necessary modifications and changes that take part in our societies (Gendron, 2008). In other words, emotional intelligence allows the leader to generate and maintain enthusiasm, serenity optimism and commitment in the organization and cooperation and mutual trust. Awareness and understanding of others' emotions allow him to gain the confidence of all stakeholders of the company. This emotional regulation facilitates the negotiations of contracts with third parties, reduced transaction costs and ensures speed. These conditions encourage the leaders to issue risky securities (Azouzi and Jarboui, 2014). The reduction of transaction costs impulse CEO access to extra debt.

H2: A leader committed accept a level of debt more than rational

\subsubsection{CEO'S Emotional Commitment Level and Equity Choice}

Modern organizations expect their employees to be full of enthusiasm and show initiative at work, they want them to take responsibility for their own development, strive for high quality and performance, be energetic and dedicated to what they do. In other words, companies want their employees be engaged (Bakker and Leiter, 2010). Other researchers state that employee engagement is the best tool in the company's efforts to gain competitive advantages and stay competitive (Rashid et al., 2011). This implies that the leader is less emotionally engaged 
downpour in the loss. It is in the position to effectively evaluate market reactions. He is aware of the financial situation of the company. It is not reluctant to issue shares to finance its investment projects.

Maslach et al. (2001) and May et al. (2004) suggested that leadership commitment affects the quality of work and their own experience to their work. It influences the growth and productivity of the organization. Thus, committed leaders' benefits likely to use their emotions to enhance their job performance. In other words, the emotional engagement allows the leader to improve its relationship with its business partners whose creditors. This facilitates the negotiations of contracts, reduces agency costs, transaction costs and ensures the speed of operations. These conditions encourage the leaders to issue risky securities (including equity preferences).

Halov and Heider (2004) defend the general idea that a strong asymmetric information about the risk of a company leads to adverse selection problem that leads companies to issue equity securities. Thus, Luthans and Youssef (2007) show that organizational commitment is positively related with optimism. In other words, optimistic and committed leader underestimates the risk of its business. He believes that the risk can be reduced by proper use of their professional skills, which led him to choose means costly external financing (external equity). The increase in risk, as measured by the volatility of securities, led to an increase in share issues. These results are based on the assumption that differences in volatility capture differences asymmetric information about the variance of cash flows arising from a managerial commitment. This implies the presence of a positive relationship between equity preferences and CEO emotional commitment level.

Frank and Goyal (2003) show a long-term relationship between levels of debt and capital. They confirm the impact of market conditions on financing choices. Parfet (2000) adds that the ability of a company to provide stable and predictable performance is a sign of good management. So, any CEO emotional committed seeks to show that good management through its financing choices. It issues shares when prices are high and go into debt or redeem shares when prices are low to benefit from favorable market trends.

Faccio et al. (2001) the dividend payment is lower in East Asia, where conflicts of interest between minority shareholders and controlling shareholders are severe, because the risk of expropriation is high because of the existence of such structures. In other words, a leader committed emotionally to manage its conflicts of interest between minority and majority shareholders. It is encouraged to minimize dividend payments. The presence of a restrictive dividend policy limit CEO preference of external financing choices (including equity ).

\section{H3: the use of the capital increase is more important for leaders committed}

\section{Research Method}

\subsection{Data}

To note, the empirical tests are based on 100 non-financial Tunisian firms during the 2010 fiscal year (28 are listed companies and 82 are non-listed companies, see Table 1). All financial firms (including banks) outing to the fact that this business sector is regulated and likely to have fundamentally different cash flows and characteristics. Firms with insufficient data regarding about emotional characteristics and the board of director's composition are also excluded. The board's compositions, as well as financial characteristics data, are gathered from the BVMT annual report.

Emotional and psychological characteristics are collected by means of an administered questionnaire. Actually, the selected choice deals with some homogeneous individuals representing some Tunisian CEO representatives of 100 firms (60 males, 35 females, 5 unreported), ranging in age from 25 to 58 (Table 2 ).

Table-1.Visited Companies

\begin{tabular}{l|l}
\hline Initial BVMT sample for 2010 & 50 \\
\hline Financialfirms & $(22)$ \\
\hline Other non financial firms & 120 \\
\hline Insufficient data to CEO Emotional Commitment & $(40)$ \\
\hline Insufficient data to board of directors compositions & $(8)$ \\
\hline Final sample & 100 \\
\hline
\end{tabular}

Table-2. CEOs' characteristics

\begin{tabular}{l|l|l}
\hline & n & Percentages \\
\hline Age & & \\
25-30 years & 5 & $5 \%$ \\
31-40 years & 20 & $20 \%$ \\
$40-49$ years & 35 & $35 \%$ \\
Over 50 years & 40 & $40 \%$ \\
\hline Gender/sex & & \\
Males & 60 & $60 \%$ \\
females & 35 & $35 \%$ \\
Unreported & 5 & $5 \%$ \\
\hline Degree & 15 & \\
Baccalaureate & 20 & $20 \%$ \\
Bac +2 & 30 & $30 \%$ \\
Bac +4 & 35 & $35 \%$ \\
DAS/HDSS & & \\
\hline
\end{tabular}

Most questionnaires have been distributed by the method of door to door to ensure they are personally delivered to the person concerned; few among them have been mailed, for businesses located outside the Greater Tunis area. 
It is worth noting, however, a broader sample that even if it had been envisaged to be studied and that more than 100 questionnaires had been distributed for this purpose, we would have received far fewer responses than expected (return rate 44.84 per cent: although the number of distributed questionnaires reached 223 , the responses received did not exceeded $100 \mathrm{CEO}$ ). Indeed, many of the adduced have refused to respond to our questions on the ground of several reasons, namely, that:

- They are too busy and have no time to devote to research;

- they generally do not pay any interest to the questionnaires submitted by students and would return them to their assistants or other staff for a response (this has been the case of our officer-centred research); and

- They perceive that the questionnaire is a sort of "control" damage to their private lives and that it is out of the question to answer.

Other encountered difficulties are mainly due to the administrative procedures and hierarchical procedures which linger questionnaires to the recoveries. Fortunately, the leaders who had been so kind as to cooperate and help us formulate and set up our sample eventually composed of 100 private company leaders, belonging mostly to the industrial sector.

\subsection{Variables' Measurement}

The objective of this section is to determine the variables' measurement.

\subsubsection{Capital Structure Choice}

The purpose of this article is to show the impact of $\mathrm{CEO}$ emotional commitment on the firm capital structure choice (internally generated resources, debt level and choosing to issue new stocks). The appropriate measures in the literature to evaluate three methods of financing are Azouzi and Jarboui (2012):

\subsubsection{Internally Generated Resources (The Cash Flow)}

Research within the framework of financial theory of investment, have resorted tomany measures of internal resources. Cash flow represents the flow generated by the activity of any business, is one of the most appropriate (Lehn and Poulsen, 1989; Molay, 2006; Naoui et al., 2008; Azouzi and Jarboui, 2012).

\section{$\mathbf{C F}=$ Net income + Depreciation - Dividend}

\section{Casch Flow rate $(\mathrm{RCF})=\mathrm{CF} /$ Total Assets}

To show that the leader chosen or not internaly generated ressources, we can use the change in flow rate. A negative change indicates the use of internal resources.

\section{Cash flow rate variation $=\mathbf{R C F} \mathbf{F}_{\mathrm{N}}-\mathbf{R C F}_{\mathrm{N}-1} / \mathbf{R C F}_{\mathrm{N}-1}$}

\subsubsection{Debt Level}

We observe a variety of variables that measure the level of debt in the company.Measures such as total debt service ratio has been selected by several authors (Hovakimian et al., 2004). Others have used the debt ratio in the medium and long term (Myers, 2001). The debt ratio in the short term was also used by Titman (1984).

As part of our analysis we propose to use the debt ratio as a measure of this variable. It should be noted that this ratio is calculated by:

\section{Leverage ratios $(\mathrm{LEV})=($ total debt $/$ total assets $)$}

This measure is also used by Koh (2003); Demaria and Dufour (2007); Jarboui and Olivero (2008); Benkraiem (2008); Sahut and Gharbi (2008) and Azouzi and Jarboui (2012).

To show that the manager uses debt or not, we can use the change in debt ratio. A positive change indicates the use of debt.

Leverage ratios variation $=\mathrm{LEV}_{\mathrm{N}}-\mathrm{LEV}_{\mathrm{N}-1} / \mathrm{LEV}_{\mathrm{N}-1}$

\subsubsection{Equity level}

This variable is measured by the value of equity in the balance sheet of the company.To show that the leader chosen or not the capital increase, we can use the variationin the percentage of investment. A positive change indicates an increase of capital (Azouzi and Jarboui, 2012).

Level of Capital Invested $(\mathrm{LCI})=$ equity / total assets

Level of Capital Invested Variation $=\operatorname{LCI}_{\mathrm{N}}-\mathbf{L C} \mathrm{I}_{\mathrm{N}-1} / \mathbf{L C I}_{\mathrm{N}-1}$

The financial decision takes 7 follows:

- 1 if the manager chooses the internally generated resources: positive variation in the cash flow rate.

- 2 if the manager chooses debt: positive variation in the leverage ratio.

- 3 if the manager chooses the capital increase: positive variation in the level of invested capital.

- 4 if the manager chooses internally generated resources + debt : positive variation in the cash flow rate and debt ratios.

- 5 if the manager chooses internally generated resources + capital increase: positive variation in the cash flow rate and level of capita invested.

- 6 if the manager chooses debt + capital increase: positive variation in the leverage ratio and level of invested capital.

- 7 if the manager chooses internally generated resources + debt+ capital increase: positive variation in the cash flow rate, leverage ratio and level of invested capital.

\subsubsection{Emotional Commitment}

To measure the CEO's commitment bias, we take the same steps as most of studies have using an adaptation of the original questionnaire elaborated by Meyer and Allen (1991) to evaluate organizational commitment (Organizational Commitment Scale). This instrument is chosen because of its validity and its multidimensional 
character shown by several researchers (Meyer et al., 2002; Azouzi and Jarboui, 2013). The questionnaire includes statements such as: "I do not feel a full member of the company "and" I'll be very happy to finish my career in this business.

The commitment bias takes the following two points (Table 3):

- 1 if the manager has a high level of this bias.

$\bullet \mathrm{O}$ if not

Table-3. Items used in the Emotionnal Commitment scale (8 Items)

\begin{tabular}{|c|c|}
\hline Items & Emotional Commitment $50.750 \%$ of total variance \\
\hline 1. I would be very happy to finish my career in my company & 0.861 \\
\hline 2. I like to discuss my firm with outsiders. & 0.851 \\
\hline 3. I feel the problems of my company like mine. & 0.842 \\
\hline $\begin{array}{l}\text { 4. I think I could easily become attached to other } \\
\text { organizations such as my firm }\end{array}$ & -0.774 \\
\hline 5. I do not feel a full member of my firm & 0.715 \\
\hline 6.I do not feel emotionally attached to my company & 0.553 \\
\hline 7.My firm at great personal meaning for me. & 0.466 \\
\hline 8. Do not feel a strong sense of belonging to my firm & 0.677 \\
\hline
\end{tabular}

\subsubsection{Profitability}

More profitable firms have, ceteris paribus, more internally generated resources to fund new investments. If their managers follow a pecking order, they will be less likely to seek external financing (Fama and French, 2002). Thus, on average, these firms' leverage ratios will be lower. In trade-off models, on the other hand, this relationship is inverted. More profitable firms are less subject to bankruptcy risks. Hence, their expected bankruptcy costs are reduced and they can make more use of the tax shields provided by debt, thus choosing a position of greater leverage. We will keep the ratio of return on assets ROA to measure this variable (Azouzi and Jarboui, 2012;2014):

ROA = Earnings before interest, tax, depreciation divided by total assets, lagged one year period

\subsubsection{Firm Size}

Studies suggest that the probability of bankruptcy is lower in larger firms and that, therefore, their debt capacity is higher than that of smaller ones, all else equal. On the other hand, fixed transaction costs can make new stock issues unattractive to small corporations, stimulating them to issue debt Rajan and Zingales (1998); Hovakimian et al. (2004); Azouzi and Jarboui (2012;2014). Indeed, most studies have applied total assets or turnover as a measure for firm size (Bujadi and Richardson, 1997). In this paper, it is measured through the log of the firm's total assets (LNSIZE).

\subsubsection{Control Variable}

\subsubsection{Future Investment Opportunities}

It is argued that future profitable investment opportunities can influence corporate financing decisions in different ways. In the context of the pecking order theory, firms that have many investment opportunities and believe that their stocks (and risky bonds) are undervalued by the market, may choose a capital structure with less debt. If they maintained high debt ratios, they would be forced to distribute precious cash flows generated by their business and could face the need to issue undervalued securities to fund new projects. This could, in turn, induce underinvestment. A more static version of the pecking order model, on the other hand, predicts that firms with more future opportunities will be more levered, ceteris paribus, because they need more external financing and issuing debt is preferable to issuing new stock (Graham, 2000; Booth et al., 2001; Naoui et al., 2008; Azouzi and Jarboui, 2012;2014).

We will keep the Tobin's $Q$ to measure this variable. The Tobin's $Q$ Estimated with the approximation formula proposed by Chung and Pruitt (1994):

$$
Q_{i t} \cong \frac{M V S_{i t}+D_{i t}}{A_{i t}}
$$

MVS - market value of common and preferred shares; D - book value of debt, defined as current liabilities plus long-term debt plus inventories minus current assets; A - total assets.

\subsubsection{Board of Directors}

To note, theories regarding the board of directors, along with prior empirical researches and various recommendations have suggested that some board characteristics have an influence on the quality of the financial report and on firms' performance. Board characteristics are examined here:, independence (Fama and Jensen, 1983).

The board's independence

The different characteristics pertaining to the board's independence are measured by the following variable: BIND is defined as the percentage of the board members who are simultaneously independent and non-executives which is equal to the number of outside directors divided by the total board members (Forker, 1992; Wright, 1996; Haniffa and Cooke, 2000; Chtourou et al., 2001; Azouzi and Jarboui, 2012).

BIND = number of outside directors / total board members.

Table 4 presents the characteristics of boards of directors of the 100 Tunisian companies included in our study. Tunisian companies are run by independent boards, medium (seven directors) and not dominated by CEOs. 
Table-4. Board of Directors' Characteristics

\begin{tabular}{|c|c|c|c|c|c|}
\hline Variables & Mean & Std & Min & $\operatorname{Max}$ & $\mathbf{N}$ \\
\hline Entire Board & 7.60 & 2.56 & 4 & 12 & 100 \\
\hline Outside Directors & 2.62 & 1.11 & 1 & 4 & 100 \\
\hline Affiliated Directors & 1.98 & 0.80 & 1 & 3 & 100 \\
\hline Inside Directors & 3.360 & 1.34 & 1 & 5 & 100 \\
\hline CEO Duality & 0.26 & 0.44 & O & 1 & 100 \\
\hline
\end{tabular}

For simplification purposes, the summary of each variable extent range in the model, its name as well as its expected impact on the firm assets specificity choice are depicted in Table 5.

Table-5. Operational definitions of variables

\begin{tabular}{|c|c|c|c|c|c|c|}
\hline Class : & Phenomena : & Mesure : & Variables : & \multicolumn{3}{|c|}{ Predictions : } \\
\hline \multicolumn{7}{|c|}{ Endogens variables : } \\
\hline \multirow[t]{3}{*}{$\begin{array}{l}\text { Capital } \\
\text { structure } \\
\text { choice }\end{array}$} & $\begin{array}{l}\text { Internally } \\
\text { resources (The Cash Flow) }\end{array}$ & $\begin{array}{l}\text { CF }=\text { Net } \\
\text { income }+ \text { Depreciation }- \\
\text { Dividend } \\
\text { Casch Flow rate }(\mathrm{RCF}) \\
=\mathrm{CF} / \text { Total Assets } \\
\text { ) } \\
\text { Cash flow rate variation } \\
=\mathrm{RCF}_{\mathrm{N}}-\mathrm{RCF}_{\mathrm{N}-1} / \mathrm{RCF}_{\mathrm{N}-1}\end{array}$ & \multicolumn{3}{|l|}{$\mathbf{C F}$} & \\
\hline & Debt level & $\begin{array}{c}\text { Leverage ratios }(\mathrm{LEV})= \\
\text { (total debt / total assets) } \\
\text { Leverage ratios variation } \\
=\mathrm{LEV}_{\mathrm{N}^{-}} \mathrm{LEV}_{\mathrm{N}-1} / \mathrm{LEV}_{\mathrm{N}-1}\end{array}$ & \multicolumn{4}{|l|}{ LEV } \\
\hline & Equity level & 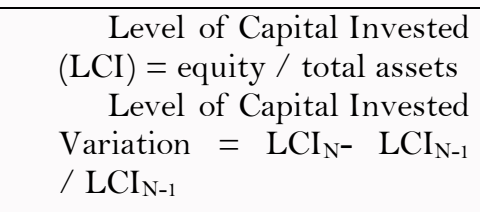 & \multicolumn{4}{|l|}{ EQ } \\
\hline \multicolumn{7}{|c|}{ Exogenous variables : } \\
\hline & & & & $\mathbf{C F}$ & LEV & EQ \\
\hline $\begin{array}{l}\text { Emotionnal } \\
\text { Commitment }\end{array}$ & $\begin{array}{l}\text { CEO identification } \\
\text { with and involvement in a } \\
\text { particular organization }\end{array}$ & $\begin{array}{l}\text { The questionnaire obtained } \\
\text { score }\end{array}$ & EC & + & + & + \\
\hline Profitability & $\begin{array}{ll}\text { Reports on } & \text { the company's } \\
\text { ability to } & \text { meet } \\
\text { commitments } & \end{array}$ & $\begin{array}{l}\text { ROA= Earnings before interest, } \\
\text { tax, depreciation divided by } \\
\text { total assets, lagged one year } \\
\text { period }\end{array}$ & PF & + & + & - \\
\hline Firm size & Firms signaled performance & Ln (total assets) & LNSIZE & + & + & + \\
\hline \multicolumn{7}{|c|}{ Controls variables: } \\
\hline $\begin{array}{l}\text { Future } \\
\text { investment } \\
\text { opportunities }\end{array}$ & $\begin{array}{l}\text { Indicates the productive } \\
\text { capacity of the company }\end{array}$ & $\begin{array}{l}Q_{i t} \cong \frac{M V S_{i t}+D_{i t}}{A_{i t}} \\
\text { MVS }- \text { market value of } \\
\text { common and preferred shares; } \\
\text { D - book value of debt, defined } \\
\text { as current liabilities plus long- } \\
\text { term debt plus inventories } \\
\text { minus current assets; A - total } \\
\text { assets. }\end{array}$ & FIO & - & + & + \\
\hline $\begin{array}{l}\text { Board of } \\
\text { Directors }\end{array}$ & $\begin{array}{l}\text { The presence of } \\
\text { independent } \\
\text { members in the } \\
\text { board }\end{array}$ & $\begin{array}{l}\text { Number of outside } \\
\text { directors / total board } \\
\text { members. }\end{array}$ & BIND & - & + & + \\
\hline
\end{tabular}

\subsection{Decision Tree Methods}

A Decision tree is a flowchart-like tree structure where each internal node (non-leaf node) denotes a test on an attribute, each branch represents an outcome of the test and each leaf node (terminal node) holds a class label. The topmost node in a tree is the root node.

A decision tree is a decision-making device which assigns a probability to each of the possible choices based on the context of the decision: $\mathrm{P}(\mathrm{f} / \mathrm{h})$, where $\mathrm{f}$ is an element of the future attributes (the set of choices) and $\mathrm{h}$ is a history (the context of the decision). This probability $\mathrm{P}(\mathrm{f} / \mathrm{h})$ is determined by asking a sequence of questions $\mathrm{q}_{1} \mathrm{q}_{2}$ $\ldots \mathrm{q}_{\mathrm{n}}$ about the context, where the $\mathrm{i}^{\text {th }}$ question asked is uniquely determined by the answers to the $\mathrm{i}-1$ previous questions. Each question asked by the decision tree is represented by a tree node and the possible answers to this question are associated with branches emanating from the node. Each node defines a probability distribution on the space of possible decisions. A node at which the decision tree stops asking questions is a leaf node. The leaf nodes represent the unique states in the decision-making problem, i.e. all contexts which lead to the same leaf node have the same probability distribution for the decision (Michae, 2006). Classification is a data mining technique that 
assigns items in a group to target class. The purpose of classification is to accurately envisage the target class for each case in the data. In our study we used the naive Bayesian classification to explain CEO investment choice. The Naive Bays classifier is a simple probabilistic classifier based on applying Bays Theorem with strong independence assumptions which assumes all of the features are equally independent. It uses a Bayesian algorithm for the total probability procedure, the principle is according to the probability that the text belongs to a category of prior probability, and the text would be assigned to the category of posterior probability. In simple terms, a naive Bays classifier assumes that the presence (or absence) of a particular feature of a class is unrelated to the presence (or absence) of any other feature.

\subsection{Define Attributes and Values}

The first step in building a decision tree is to list the variables recursively, starting from the target variable to the causes. In this order we present the variables in the table below:

Table-6. The attributes and their values

\begin{tabular}{r|r}
\hline Attributes & Type \\
\hline Capital structure choice & Discret $[1 ; 2 ; 3]$ \\
\hline Emotionnal Commitment & Discret : YES/NO \\
\hline Frofitability & Discret : YES/NO \\
\hline Future investment opportunities & Discret $[1 ; 2 ; 3]$ \\
\hline Board Independence & Discret : YES/NO \\
\hline
\end{tabular}

\section{Empirical Results}

\subsection{Graphical Model Analysis}

\section{Capital Structure Choice Modality: [1.2.3.4.5.6.7]}

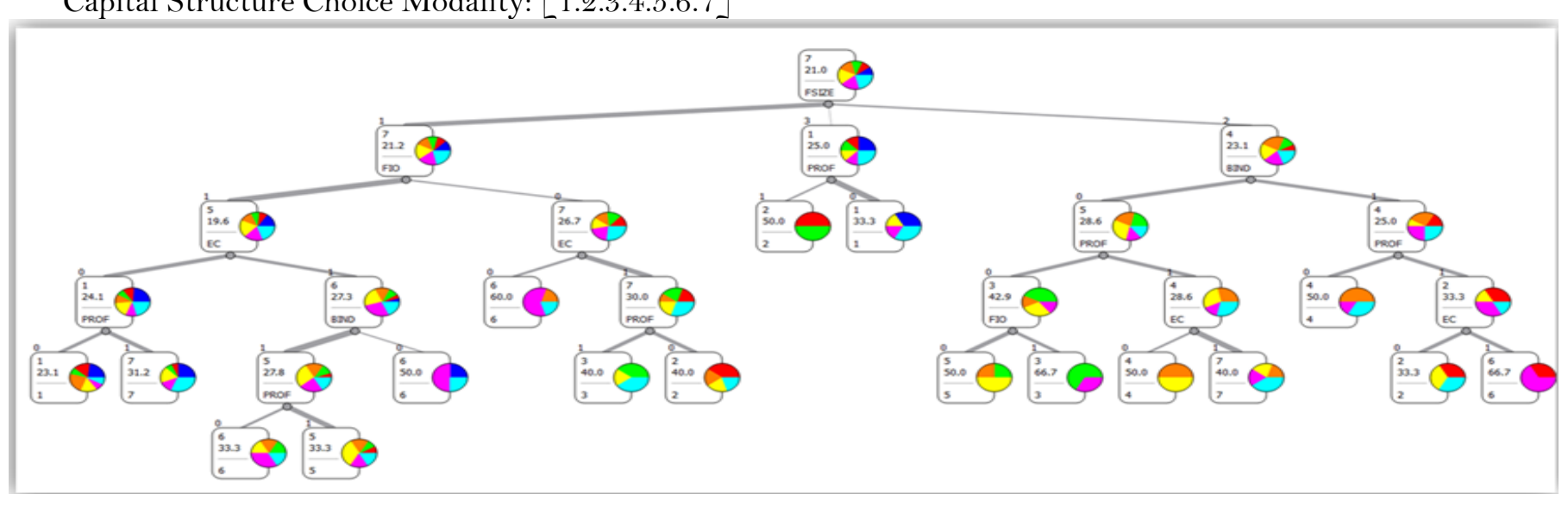

Internally Generated Resources

Debt

Equity

4.Internally Generated Resources+ Debt

5. Internally Generated Resources +Equity
Debt+Equity

7. Internally Generated Resources+ Debt+Equity

\begin{tabular}{ll}
\multicolumn{1}{c}{ Table-7. Attribute Statistic } \\
\hline Attribute & Probability \% \\
\hline Capital structure choice (CSC) & 100 \\
\hline Internally Generated Resources & 10 \\
\hline Debt & 9 \\
\hline Equity & 10 \\
\hline Internally Generated Resources+ Debt & 14 \\
\hline Internally Generated Resources +Equity & 18 \\
\hline Debt + Equity & 48 \\
\hline Internally Generated Resources+ Debt+Equity & 21 \\
\hline Emotional commitment (EC) & 100 \\
\hline Yes :1 & 55 \\
\hline No : 0 & 45 \\
\hline Profitability (PROF) & 100 \\
\hline Yes :1 & 54 \\
\hline No : 0 & 46 \\
\hline Firm size (FSIZE) & 100 \\
\hline Small :1 & 66 \\
\hline Bedium : $: 3$ & 26 \\
\hline Yes : 1 & 8 \\
\hline No : 0 & 100 \\
\hline Yes : 1 & 85 \\
\hline No : 0 & 15 \\
\hline Board independency (BIND) & 100 \\
\hline Note that the decision tree that has been built gives us information on the relevance of attributes about the
\end{tabular}

Note that the decision tree that has been built gives us information on the relevance of attributes about the target variable (firm capital structure choice): 
The graphical model shows that the size is "is the first variable used; is called segmentation variable. This is the most relevant in the analysis of $\mathrm{CEO}$ capital structure preferences $(\mathrm{P}=0.21$ for the choice of capital structure mode: Internally Generated Resources+ Debt+Equity). As it is composed of three terms \{small, medium, large\}, so she produced three peaks children. The first edge (the first leg), left, on the second level, is produced from the "average" category of the variable "size". The resulting top cover 2 observation. It indicates the Future investment opportunities (FIO) \{Yes / No\}. The frequency distribution shows that for a leader to medium size firm and Future investment opportunities chosen capital structure mode 7 namely Internally Generated Resources+ Debt+Equity a probability of $21.2 \%$. The second ridge in the center corresponds to the "large" category of the segmentation variable "size"; the corresponding vertex cover 2 observation. It shows the profitability level of the company $\{$ Yes/ No $\}$. The frequency distribution shows that for a large company is performing selected one of the capital structure terms are: Internally Generated Resources with a probability of $25 \%$.

The third ridge, right, is the "small" category of the segmentation variable "size"; the corresponding vertex cover 2 observation. It indicates the degree of independence of the board \{Yes / No\}. The frequency distribution shows that, for the Tunisian small businesses that their advice is independent, leaders prefer a combination of Internally Generated Resources+ Debt with a probability of $23.3 \%$.

Let the third level of the tree to the left, we see that the variable future investment opportunities (FIO)turns into a segmentation variable. As it is composed of two modality \{Yes / No\}, we note the presence of two branches. Thus, the first edge on the left, on the third level, is produced from the "no" category of the variable " Future investment opportunities ". The resulting top cover 2 observation. It indicates the level of CEO emotional commitment $\{$ Yes/ No\}. The frequency distribution shows that the CEO prefer Internally Generated Resources+ Debt+Equity with a probability of $26.7 \%$ due to their emotional commitment. The second part is produced from the modality "yes" to the variable " Future investment opportunities ". The resulting top cover 2 observation. It indicates the level of CEO emotional commitment $\{$ Yes / No $\}$. The frequency distribution shows that the engaged prefer Internally Generated Resources +Equity with a probability of $29 . \%$.

Still remain on the third level to the right of the tree, there is the variable of board independence as segmentation variable. As it is composed of two modality $\{$ yes / no $\}$, we note the presence of two branches. Thus, the first edge on the left, on the third level, is produced from the modality "yes" to the variable "independent counsel." The resulting top cover 2 observation. It indicates the firm profitability level $\{$ Yes / No $\}$. The frequency distribution shows that the leaders of profitable firm with independent advice and choose the Internally Generated Resources+ Debt with a probability of $25 \%$. The second part is produced from the "no" category of the variable "independent board." The resulting top cover 2 observation. It indicates the level of profitability of the company $\{$ Yes/ No\}. The frequency distribution shows the least profitable companies that their advice is independent opting Internally Generated Resources +Equity to probability 28.6\%. This process is repeated on each vertex of the tree until pure leaves. Thus, the pure or pure tree leaf in our study corresponds to level 5 . The right part of level 5 shows that companies, profitable firm, small size and independent advice to choose the Debt and combination between debt+ equity with the following probabilities: $33.33 \%$ and $66.7 \%$ due to their leaders' emotional commitment high level. We also note that Tunisian companies small, less profitability level and independent incentive leader to undertake Internally Generated Resources+ Debt to probability 50\%. Tunisian companies small, independency small level, profitable have emotionally committed leader. This emotional bias incited him to prefer Internally Generated Resources+ Debt and Internally Generated Resources+ Debt+Equity with the following probabilities: $50 \%$ and $40 \%$. Tunisian companies small, independency small level, profitability small level prefer Internally Generated Resources +Equity and Equity with the following probabilities: 50\% and 66.7\%.

Let the left of the pure tree parts, the results of our classification argue that Tunisian emotionally engaged leaders in medium size firm, profitable, future investment opportunities and independent opt for Internally Generated Resources +Equity with a probability of 33.33\%. They use Debt + Equity with a probability of $33.33 \%$ if the profitability of their firms is low. Then these engaged leaders realize the Equity with a probability of $40 \%$ when the level of board independence and corporate future investment opportunities levels are low. However, companies use Debt with a probability of $40 \%$. This choice is justified by the low level of emotionally engaged leaders despite high profitability of these firms.

\subsection{Cross Validation Analysis}

For measuring performance classification techniques the following parameters are taken. In Classification techniques parameters to be examined are accuracy, sensitivity, precision, specificity and f-measure.

\section{Classification Accuracy}

Accuracy is the percent of correct classifications. Accuracy is the overall correctness of the model and is calculated as the sum of correct classifications divided by the total number of classifications. We note that this ratio is low for 7 classes of capital structure choice (13\%).

\section{Sensitivity}

Sensitivity is a measure of the ability of a prediction model to select instances of a certain class from a data set. It is corresponds to the true positive rate. We note that the capital structure preferences of Tunisian companies are divided into the following 4 conditions:

- Internally Generated Resources with a completion rate of $30 \%$

- Internally Generated Resources + Equity with a completion rate of $22.22 \%$

- Debt+ Equity with a completion rate of $5.56 \%$ and

- Internally Generated Resources+ Debt+Equity with a completion rate of $23.81 \%$ 
Table-8. Cross Validation analysis (CSC).

\begin{tabular}{|c|c|c|c|c|c|c|c|}
\hline \multicolumn{8}{|c|}{ Internally Generated Resources } \\
\hline Methods & $\begin{array}{l}\text { Classification } \\
\text { accuracy }\end{array}$ & Sensitivity & specificity & F-mesure & Precision & $\begin{array}{l}\text { Matthews } \\
\text { coefficient }\end{array}$ & correlation \\
\hline Naive Bayes & 0.1300 & 0.3000 & 0.8333 & 0.2143 & 0.1667 & 0.1041 & \\
\hline \multicolumn{8}{|l|}{ Debt } \\
\hline Methods & $\begin{array}{l}\text { Classification } \\
\text { accuracy }\end{array}$ & Sensitivity & specificity & F-mesure & Precision & $\begin{array}{l}\text { Matthews } \\
\text { coefficient }\end{array}$ & correlation \\
\hline Naive Bayes & 0.1300 & 0.0000 & 0.9670 & $\mathrm{~N} / \mathrm{A}$ & 0.0000 & -0.0553 & \\
\hline \multicolumn{8}{|l|}{ Equity } \\
\hline Methods & $\begin{array}{l}\text { Classification } \\
\text { accuracy }\end{array}$ & Sensitivity & specificity & F-mesure & Precision & $\begin{array}{l}\text { Matthews } \\
\text { coefficient }\end{array}$ & correlation \\
\hline Naive Bayes & 0.1300 & 0.0000 & 0.9222 & $\mathrm{~N} / \mathrm{A}$ & 0.0000 & -0.0915 & \\
\hline \multicolumn{8}{|c|}{ Internally Generated Resources+ Debt } \\
\hline Methods & $\begin{array}{l}\text { Classification } \\
\text { accuracy }\end{array}$ & Sensitivity & specificity & F-mesure & Precision & $\begin{array}{l}\text { Matthews } \\
\text { coefficient }\end{array}$ & correlation \\
\hline Naive Bayes & 0.1300 & 0.0000 & 0.8488 & $\mathrm{~N} / \mathrm{A}$ & 0.0000 & -0.1560 & \\
\hline \multicolumn{8}{|c|}{ Internally Generated Resources +Equity } \\
\hline Methods & $\begin{array}{l}\text { Classification } \\
\text { accuracy }\end{array}$ & Sensitivity & specificity & F-mesure & Precision & $\begin{array}{l}\text { Matthews } \\
\text { coefficient }\end{array}$ & correlation \\
\hline Naive Bayes & 0.1300 & 0.2222 & 0.7561 & 0.1905 & 0.1667 & -0.0195 & \\
\hline \multicolumn{8}{|l|}{ Debt+ Equity } \\
\hline Methods & $\begin{array}{l}\text { Classification } \\
\text { accuracy }\end{array}$ & Sensitivity & specificity & F-mesure & Precision & $\begin{array}{l}\text { Matthews } \\
\text { coefficient }\end{array}$ & correlation \\
\hline Naive Bayes & 0.1300 & 0.0556 & 0.8780 & 0.0690 & 0.0909 & -0.0815 & \\
\hline \multicolumn{8}{|c|}{ Internally Generated Resources+ Debt+Equity } \\
\hline Methods & $\begin{array}{l}\text { Classification } \\
\text { accuracy }\end{array}$ & Sensitivity & specificity & F-mesure & Precision & $\begin{array}{l}\text { Matthews } \\
\text { coefficient }\end{array}$ & correlation \\
\hline Naive Bayes & 0.1300 & 0.2381 & 0.87595 & 0.2222 & 0.2083 & -0.0023 & \\
\hline
\end{tabular}

\section{Specificity}

Specificity measures the proportion of negatives who are correctly identified (e.g. the percentage of well people who are identified as not having the condition). In our study the specificity measures the percentage of companies that have not chosen the capital structure mode. we note that this percentage between $70 \%$ and $90 \%$. This is explained by the Tunisian leaders made that are not aware of the presence of these combination.

\section{F- Mesure}

It corresponds to the margin of error around the exact solution. we note that the capital structure preferences of Tunisian companies are divided into the following 4 conditions with a low margin of error between 0.06 and 0.22:

- Internally Generated Resources with an error rate of $21.43 \%$

- Internally Generated Resources +Equity with an error rate of $19.05 \%$

- Debt+ Equity with an error rate of $6.90 \%$ and

- Internally Generated Resources+ Debt+Equity with an error rate of $22.22 \%$

We note that all the variables chosen for the analysis of CEO capital structure preferences (firm size, CEO emotional commitment, the investment opportunities, profitability and the board independence) explain that the following 4 capital structure choice categories namely:

Internally Generated Resources: This result affirms our theoretical prediction (H1): An engaged leader accepts a internally generated resources level greater than that debt (and / or equity): A committed leader seeks to avoid the adverse consequences of financial distress (loss of brand image on the market leaders ...). He prefers to finance its investments by internal capital at the expense of external financing modes (risky).

Internally Generated Resources +Equity: This result confirms our hypothesis (H3): organizational commitment is positively related with optimism. In other words, optimistic and committed leader underestimates the risk of its business. He believes that the risk can be reduced by proper use of their professional skills, which led him to choose means costly external financing (external equity). The increase in risk, as measured by the volatility of securities, led to an increase in share issues. These results are based on the assumption that differences in volatility capture differences asymmetric information about the variance of cash flows arising from a managerial commitment.

Debt+ Equity This result confirms our hypothesis (H2): organizational commitment is positively related with optimism. Fairchild (2009) adds that optimistic leader (high emotional commitment level) overestimates the capacity of its business and underestimate the costs of financial distress. This evaluation bias (hopefully) makes him choose debt as a financing of these investment projects. Thus, Malmendier and Tate (2005;2008); Malmendier and Tate (2015) find that the optimistic manager will give priority to self-financing, then debt and ultimately to the issuance of shares. Thus, if the flow of the company is insufficient capacity, it is useful to resort to external financing. The optimistic leader always prefers debt (reported by debt) to the capital increase: the Pecking Order Theory (Azouzi and Jarboui, 2012).

Internally Generated Resources+ Debt+Equity: This result confirms the Pecking Order Theory: optimistic and committed leader underestimates the risk of its business. He believes that the risk can be reduced by proper use of their professional skills, which led him to choose means costly external financing (external equity). The increase in risk, as measured by the volatility of securities, led to an increase in share issues. These results are based on the assumption that differences in volatility capture differences asymmetric information about the variance of cash flows arising from a managerial commitment. Thus, Malmendier and Tate (2005;2008); Malmendier and Tate (2015) find that the optimistic manager will give priority to self-financing, then debt and ultimately to the issuance of shares. 


\section{Conclusion}

This research examines the determinants of firms 'capital structure choice introducing a behavioral perspective. Theoretical analysis presented implications of managerial emotional commitment to explain his preference for financial decision. internally generated resources analysis by introducing managerial affective commitment enriched organizational financial theory: Affective commitment is positively related to positive discretionary behaviors. So any CEO engaged threatened by the risk of loss of social status seeking to value his work at the head of his company through effective financial choices. He prefers to finance its investments by internal capital at the expense of external financing modes (risky).

The managerial commitment analysis of debt preference suggested that commitment level is part of the motivation. They showed that the CEO commitment level is positively correlated with its motivation. This committed leader (motivated) looking through strategic choices (including debt financing decision) report the performance of its business. The leader chosen for debt project finance and performance reports (maximizes shareholder wealth in place and refuse the entry of new shareholders) of the firm that pushes analysts to reassess.

The relationship between firm equity choice and CEO affective commitment show that optimistic and committed leader underestimates the risk of its business. He believes that the risk can be reduced by proper use of their professional skills, which led him to choose means costly external financing (external equity). The increase in risk, as measured by the volatility of securities, led to an increase in share issues. These results are based on the assumption that differences in volatility capture differences asymmetric information about the variance of cash flows arising from a managerial commitment.

Empirical analysis presenting survey CEO large private companies in Tunisia. Data analyses revealed CEO emotional commitment level importance in explaining his financial decision. the decision tree analysis of the relationship between CEO affective commitment level and investment policy confirm theoretical prediction. Thus, decision tree cross validation analysis suggested that financial preferences of Tunisian companies are divided into the following 4 conditions with a low margin of error between 0.06 and 0.22 :

- Internally Generated Resources with an error rate of $21.43 \%$

- Internally Generated Resources +Equity with an error rate of $19.05 \%$

- Debt+ Equity with an error rate of $6.90 \%$ and

- Internally Generated Resources+ Debt+Equity with an error rate of $22.22 \%$

Finally, this paper proposes a decision tree model for specifying the importance of CEO commitment level causing financial decision analysis. Thus, decision tree model postulate that psychological dimension introduced in the capital structure analysis has enriched the Pecking Order Theory (POT) and the Static Trade Off Theory (STT) (Graham and Harvey, 2001; Heaton, 2002; Lin et al., 2008; Azouzi and Jarboui, 2012).

\section{References}

Allen, N.J. and J.P. Meyer, 1990. The measurement and antecedents of affective, continuance and normative commitment to the organization. Journal of Occupational Psychology, 63(1): 1 -18. View at Google Scholar | View at Publisher

Allen, N.J. and J.P. Meyer, 1996. Affective, continuance and normative commitment to the organization: An examination of construct validity. Journal of Vocational Behavior, 49(3): 252 -276. View at Google Scholar | View at Publisher

Azouzi, M.A. and A. Jarboui, 2012. CEO emotional bias and capital structure choice: Bayesian network method. Business Management and Excellence, 2(2): 47-70. View at Google Scholar

Azouzi, M.A. and A. Jarboui, 2013. Why CEO emotional biases affect firm assets specificity choice bayesian network method: The evidence from Tunisia. Asian Journal of Empirical Research, 3(3): 329-350. View at Google Scholar

Azouzi, M.A. and A. Jarboui, 2014. CEO emotional intelligence and firms financial policies: Bayesian network method. Contemporary Economics, 8(1): 5-24. View at Google Scholar | View at Publisher

Baker, T., M.C. Andrews and T.G. Hunt, 2011. Values and person-organization fit: Does moral intensity strengthen outcomes. Leadership \& Organization Development Journal, 32(1): 5-19. View at Google Scholar | View at Publisher

Bakker, A.B. and M.P. Leiter, 2010. Work engagement: A handbook of essential theory and research. New York, USA: Psychology Press. pp: 224.

Barton, S.L. and P.J. Gordon, 1987. Corporate strategy: Useful perspective for the study of capital structure? Academy of Management Review, 12(1): 67-75. View at Google Scholar | View at Publisher

Barton, S.L., N.C. Hill and S. Sundaram, 1989. An empirical test of stakeholder theory predictions of capital structure. Financial Management, 18(1): 36-44. View at Google Scholar | View at Publisher

Benkraiem, R., 2008. The influence of institutional investors on opportunistic earnings management. International Journal of Accounting, Auditing and Performance Evaluation, 5(1): 89-106. View at Google Scholar | View at Publisher

Bentein, K., R. Vandenberg, C. Vandenberghe and F. Stinglhamber, 2005. The role of change in the relationship between commitment and turnover: A latent growth modeling approach. Journal of Applied Psychology, 90(3): 468-482. View at Google Scholar |View at Publisher

Bertrand, M. and M. Sendhil, 2003. Enjoying the quiet life? Corporate governance and managerial preferences. Journal of Political Economy, 11 1(5): 1043-1075. View at Google Scholar | View at Publisher

Booth, L., V. Aivazian, A. Demirguc-Kunt and V. Maksimovic, 2001. Capital structures in developing countries. Journal of Finance, 56(1): 87-130. View at Google Scholar

Bujadi, M.L. and A.J. Richardson, 1997. A citation trail review of the uses of firme size in, accounting research. Journal of Accounting Literature, 16(1): 1-27. View at Google Scholar

Carmeli, A., 2003. The relationship between emotional intelligence and work attitudes, behavior and outcomes: An examination among senior managers. Journal of Managerial Psychology, 18(8): 788-813. View at Google Scholar | View at Publisher

Chang, C., A.C. Lee and C.F. Lee, 2009. Determinants of capital structure choice: A structural equation modeling approach. Quarterly Review of Economics and Finance, 49(2): 197-2 13. View at Google Scholar | View at Publisher

Chtourou, S.M., J. Bedard and L. Courteau, 2001. Corporate governance and earning management. Working Paper, Social Science Research Network. Canada, UK: Laval University.

Chung, K.H. and S.W. Pruitt, 1994. A simple approximation of Tobin's q. Financial Management, 23(3): 70 -74. View at Google Scholar| View at Publisher

Cohen, A., 2003;2007. Multiple commitments in the workplace: An integrative approach. Mahwah, NJ: Lawrence Erlhaum Associates. pp: 354.

De Clercq, D., T.V. Menzies, M. Diochon and Y. Gasse, 2009. Explaining nascent entrepreneurs' goal commitment: An exploratory study. Journal of Small Business \& Entrepreneurship, 22(2): 123-139. View at Google Scholar | View at Publisher

Demaria, S. and D. Dufour, 2007. The choice of accounting option for the transition to IAS/IFRS: What role of caution? Accounting and Control- Audit, 13(3): 195-2 18. View at Google Scholar

Faccio, M., L.H.P. Lang and L. Young, 2001. Dividends and expropriation. American Economic Review, 91(1): 54 -78. View at Google Scholar | View at Publisher 
Fairchild, R., 2009. Managerial overconfidence, moral hazard problems and excessive life-cycle debt sensitivity. Investment Management and Financial Innovations, 6(3): 55-1 10. View at Google Scholar

Fama, E.F. and K.R. French, 2002. Testing trade-off and pecking order predictions about dividends and debt. Review of Financial Studies, 15(1): 1-33. View at Google Scholar | View at Publisher

Fama, E.F. and M.C. Jensen, 1983. Separation of ownership and control. Journal of Law and Economics, 26(2): 301 -325. View at Google Scholar

Forker, J.J., 1992. Corporate governance and disclosure quality. Accounting and Business Research, 22(86): 111-124. View at Google Scholar

Frank, M.Z. and V.K. Goyal, 2003. Testing the pecking order theory of capital structure. Journal of Financial Economics, 67(2): $217-248$. View at Google Scholar | View at Publisher

Garg, N., B. Wansink and J.J. Inman, 2007. The influence of incidental affect on consumers' food intake. Journal of Marketing, 71 (1): 194206. View at Google Scholar | View at Publisher

Gendron, B., 2008. Emotional capital and emotional work: Emotional competencies as teacher professional competencies to teach for learning. Proceedings of the European Conference on Educational Research, September 10-12, 2008, Goteborg, Sweden.

Girandola, F. and F. Michelik, 2008. Engagement and persuasion by fear: Towards an engaging communication in the field of health. Canadian Journal of Behavioural, 4O(2): 69-79. View at Google Scholar

Glazer, S. and B. Kruse, 2008. The role of organizational commitment in occupational stress models. International Journal of Stress Management, 15(4): 329-344. View at Google Scholar | View at Publisher

Goleman, D., R. Boyalzis and A. Mikee, 2001. Primal leadership: The hidden driver of great performance. Harvard Business Review, 79(11): 42-53. View at Google Scholar

Graham, J.R., 2000. How big are the tax benefits of debt? Journal of Finance, 55(5): 1901-1940. View at Google Scholar | View at Publisher

Graham, J.R. and C.R. Harvey, 2001. The theory and practice of corporate finance: Evidence from the field. Journal of Financial Economics, 60(2-3): 187-243. View at Google Scholar

Greenberg, J. and R.A. Baron, 2003. Behavior in organizations: Understanding and managing the human side of work. 8th Edn., Upper Saddle River, NJ: Prentice Hall. pp: 691.

Halov, N. and F. Heider, 2004. Capital structure, risk and asymmetric information. Working Paper. New York, USA: New York University.

Haniffa, R. and T. Cooke, 2000. Culture, corporate governance and disclosure in Malaysian corporations. Proceedings of the Asian AAA World Conference, August 28-30, 2000, Singapore.

Heaton, J.B., 2002. Managerial optimism and corporate finance. Financial Management, 31(2): 33-46. View at Google Scholar | View at Publisher

Helliar, C.V., D.M. Power and C.D. Sinclair, 2005. Managerial irrationality in financial decision making. Management Finance, $31(4)$ : $1-11$. View at Google Scholar $\mid$ View at Publisher

Hilary, G. and L. Menzly, 2006. Does past success lead analysts to become overconfident? Management Science, 52(4): 489-500. View at Google Scholar | View at Publisher

Hovakimian, A., G. Hovakimian and H. Tehranian, 2004. Determinants of target capital structure: The case of dual debt and equity issues. Journal of Financial Economics, 7 1(3): 517-540. View at Google Scholar | View at Publisher

Humphreys, J., B. Brunsen and D. Davis, 2005. Emotional structure and commitment: Implications for health care management. Journal of Health Organization and Management, 19(2): 120-129. View at Google Scholar | View at Publisher

Jalilvand, A. and R.S. Harris, 1984. Corporate behavior in adjusting to capital structure and dividend targets: An econometric study. Journal of Finance, 39(1): 127-145. View at Google Scholar | View at Publisher

Jarboui, A. and B. Olivero, 2008. Is the risk / time horizon pair of investments governed by the institutional and dominant shareholders? [the couple's risk / time horizon of the investment being led by institutional and dominant shareholders]. Bank Markets, 93(1): 2034. View at Google Scholar

Koh, P.S., 2003. On the association between institutional ownership and aggressive corporate earnings management in Australia. British Accounting Review, 35(2): 105-128. View at Google Scholar | View at Publisher

Kundi, G.M., A. Nawaz and B. Shah, 2007. Politics in IT projects. Gomal University Journal of Research, 23(2): 211-215. View at Google Scholar

Lee, Y.J., I.C. Lee and C.L. Lin, 2014. The effects of employees' satisfaction and leadership styles on organizational performance: Organizational commitment as a dual mediator. Asian Journal of Empirical Research, 4(2): 104-124. View at Google Scholar

Lehn, K. and A. Poulsen, 1989. Free cash flow and stockholder gains in going private transactions. Journal of Finance, 44(3): 771-787. View at Google Scholar | View at Publisher

Lin, Y.H., S.Y. Hu and M.S. Chen, 2008. Testing pecking order prediction from the viewpoint of managerial optimism: Some empirical evidence from Taiwan. Pacific-Basin Finance Journal, 16(1-2): 160-181. View at Google Scholar $\mid$ View at Publisher

Luthans, F. and C.M. Youssef, 2007. Emerging positive organizational behavior. Journal of Management, 33(3): 32 1-349. View at Google Scholar | View at Publisher

Malmendier, U. and G. Tate, 2005. CEO overconfidence and corporate investment. Journal of Finance, 60(6): 2661-2700. View at Google Scholar | View at Publisher

Malmendier, U. and G. Tate, 2008. Who makes acquisitions? CEO overconfidence and the market's reaction. Journal of Financial Economics, 89(1): 20-43. View at Google Scholar | View at Publisher

Malmendier, U. and G. Tate, 2015. Behavioral CEOs: The role of managerial overconfidence. Journal of Economic Perspectives, 29(4): 3760. View at Google Scholar | View at Publisher

Maslach, C., W.B. Schaufeli and M.P. Leiter, 2001. Job burnout. Annual Review of Psychology, 52(1): 397-422. View at Google Scholar

May, D.R., R.L. Gilson and L.M. Harter, 2004. The psychological conditions of meaningfulness, safety and availability and the engagement of the human spirit at work. Journal of Occupational and Organizational Psychology, 77(1): 11-37. View at Google Scholar |View at Publisher

Mayers, S. and N. Majluf, 1984. Corporate financing and investment decisions when firms have information that investors do not have. Journal of Financial Economics, 13(2): 187-221. View at Google Scholar | View at Publisher

McDonald, D.J. and P.J. Makin, 2000. The psychological contract, organisational commitment and job satisfaction of temporary staff. Leadership \& Organization Development Journal, 2 1(2): 84-91. View at Google Scholar | View at Publisher

Meyer, J.P. and N.J. Allen, 1991. A three-component conceptualization of organizational commitment. Human Resource Management Review, 1(1): 61-89. View at Google Scholar | View at Publisher

Meyer, J.P. and N.J. Allen, 1997. Commitment in the workplace: Theory, research and application. Thousand Oaks, CA., USA: Sage Publications. pp: 150 .

Meyer, J.P., T.E. Becker and C. Vandenberghe, 2004. Employee commitment and motivation: A conceptual analysis and integrative model. Journal of Applied Psychology, 89(6): 991-1007. View at Google Scholar | View at Publisher

Meyer, J.P., D.J. Stanley, L. Herscovitch and L. Topolnytsky, 2002. Affective, continuance, and normative commitment to the organization: A meta-analysis of antecedents, correlates and consequences. Journal of Vocational Behavior, 61(1): 20-52. View at Google Scholar | View at Publisher

Michae, N., 2006. Large database decision tree classifiers. Decision Trees \& Data Mining, 49(1): 62-68.

Molay, E., 2006. A test of the pecking order theory of French panel data. Working Paper, University of Nice IAE.

Mowday, R.T., R.M. Steers and L.W. Porter, 1979. The measurement of organizational commitment. Journal of Vocational Behavior, 14(2): 224-247. View at Google Scholar

Myers, S.C., 2001. Capital structure. Journal of Economic perspectives, 15(2): 81-102. View at Google Scholar

Naoui, K., M. Elgaied and F. Bayoudh, 2008. Internal financing and investment: Information asymmetry vs managerial discretion. Retrieved from http://ssrn.com/abstract=1118416.

O'Reilly, C.A. and J. Chatman, 1986. Organizational commitment and psychological attachment: The effects of compliance, identification and internalization on prosocial behavior. Journal of Applied Psychology, 71(3): 492-499. View at Google Scholar | View at Publisher

Organ, D.W. and K. Ryan, 1995. A meta-analytic review of attitudinal and dispositional predictors of organizational citizenship behavior. Personnel Psychology, 48(4): 775-802. View at Google Scholar | View at Publisher

Parfet, W.U., 2000. Accounting subjectivity and earnings management: A preparer perspective. Accounting Horizons, 14(4): 481-488. View at Google Scholar | View at Publisher

Philippot, P., 2007. Emotion and psychotherapy. Wavre, Belgium: Mardaga. pp: 250.

Porter, L.W., R.M. Steers, R.T. Mowday and P.V. Boulian, 1974. Organizational commitment, job satisfaction, and turnover among psychiatric technicians. Journal of Applied Psychology, 59(5): 603-609. View at Google Scholar | View at Publisher 
Rajan, R.G. and L. Zingales, 1998. Power in a theory of the firm. Quarterly Journal of Economics, 133(2): 387-432. View at Google Scholar

Rashid, H.A., A. Asad and M.M. Ashraf, 2011. Factors persuading employee engagement and linkage of EE to personal and organizational performance. Interdisciplinary Journal of Contemporary Research in Business, 3(5): 98-108. View at Google Scholar

Robbins, S.P., 2001 . Organizational behavior: Concepts, controversies, applications. 8th Edn., New York: Prentice Hall.

Rocha, F.D.S., L. Cardoso and N. Tordera, 2008. The importance of organizational commitment to knowledge management. Organizational Behavior and Management, 14(2): 211-232. View at Google Scholar

Rosete, D. and J. Ciarrochi, 2005. Emotional intelligence and its relationship to workplace performance outcomes of leadership effectiveness. Leadership \& Organization Development Journal, 26(5): 388-399. View at Google Scholar | View at Publisher

Ross, S., 1977. The determination of financial structure: The incentive signalling approach. Bell Journal of Economics, 8(1): 23-40. View at Google Scholar |View at Publisher

Sahut, J.M. and O. Gharbi, 2008. Institutionals investors and firm value. Working Paper University Poitiers and Paul Cézanne.

Shore, L.M. and S.J. Wayne, 1993. Commitment and employee behavior: Comparison of affective commitment and continuance commitment with perceived organizational support. Journal of Applied Psychology, 78(5): 774-780. View at Google Scholar | View at Publisher

Siu, A.F., 2009. Trait emotional intelligence and its relationships with problem behavior in Hong Kong adolescents. Personality Individual Differences, 47(6): 553-557. View at Google Scholar | View at Publisher

Solinger, O.N., W. van Olffen and R.A. Roe, 2008. Beyond the three-component model of organizational commitment. Journal of Applied Psychology, 93(1): 70- 83. View at Google Scholar |View at Publisher

Somers, M. and D. Birnbaum, 2000. Exploring the relationship between commitment profiles and work attitudes, employee withdrawal and job performance. Public Personnel Management, 29(3): 353-366. View at Google Scholar | View at Publisher

Stulz, R., 1990. Managerial discretion and optimal financing policies. Journal of Financial Economics, 26(1): 3-27. View at Google Scholar | View at Publisher

Swailes, S., 2004. Commitment to change: Profiles of commitment and in-role performance. Personnel Review, 33(2): 187-204. View at Google Scholar | View at Publisher

Titman, S., 1984. The effect of capital structure on a firm's liquidation decision. Journal of Financial Economics, 13(1): 137-151. View at Google Scholar | View at Publisher

Titman, S. and R. Wessels, 1988. The determinants of capital structure choice. Journal of Finance, 43(1): 1-19. View at Google Scholar | View at Publisher

Tsai, K.Y., 1999. Employees' satisfacton, work involvemnt and organizational commitment in electronics industry. Summer Research Project, Part-Time Program, Institute of Human Resource Management, National Sun Yat-Sen University, Taiwan.

Wright, D.W., 1996. Evidence on the relation between corporate governance characteristics and the quality of financial reporting. Working Paper, University of Michigan. 